\title{
Rural Livelihood Challenges: Moving out of Agriculture
}

\subsection{INTRODUCTION}

Narratives around poverty, hunger, food security and nutrition-largely subsumed in the food system-are intrinsically linked to the development of the rural economy. Rural economic structure is constantly reshaped by forces of urbanization, expanding markets, returns to livelihood opportunities, changes in land use patterns and the inherent socio-demographic structure of villages. Also, the reliance on cultivation as the main source of livelihood in rural areas is declining with the growth of smaller towns and non-farm livelihood opportunities. Thus, the future of agricultural work will look very different from what we have seen.

The theory of structural transformation suggests a decline in agriculture's share in total output and employment over time. As people move out of agriculture, household income and access to non-farm economic opportunities - rather than just farm-level production diversity or farm incomes-become equally important predictors of household food and nutrition security. This is driven by the fact that, as agricultural systems modernize and markets develop, there is an increasing separation between the production and consumption decisions of households (Pingali \& Sunder, 2017). As a result, home consumption declines and food security concerns progressively become an issue of access rather than availability. To enhance access to nutrition and food, when most households progressively become net consumers of food, household income becomes the

(C) The Author(s) 2019

P. Pingali et al., Transforming Food Systems for a Rising India, Palgrave Studies in Agricultural Economics and Food Policy, https://doi.org/10.1007/978-3-030-14409-8_3 
most important instrument for improving welfare. ${ }^{1}$ The logical question therefore ensues: how can one increase income earning opportunities in rural areas such that it increases food security and welfare? The development world has taken note of the fact that income diversification is key to rural development, poverty reduction and food security and the same applies to India as well. Along the path of structural transformation, the non-farm sector in India has gains in prominence becoming an important pathway for increasing food security.

In the last four decades, Indian rural output has increased by almost seven times-Rs. 3,199 billion to Rs. 21,107 billion at 2004-05 prices-but the share of agriculture in rural income has reduced from $72.4 \%$ to $39.2 \%$ (Chand, Srivastava, \& Singh, 2017). Pathways from agriculture to nutrition mostly assume farming - as a source of income and food-to be the most important means to access food in rural economies. However, a greater share of households in rural India now rely on markets to access food. ${ }^{2}$ Nationally representative data suggests that $88 \%$ of farming households rely on some form of non-farm income sources to sustain their livelihoods (Chandrasekhar \& Mehrotra, 2016). Non-farm income is therefore becoming an important source of food security and dietary diversity (Mishra \& Rahman, 2018). Livelihood and income diversification out of farming have been considered as desirable for enabling greater structural transformation. By moving underemployed agricultural labor towards non-farm economic opportunities, it is expected to enhance capabilities and raise household living standards (Ellis, 1998). During times of distress such as weather shocks, non-agricultural labor supply is generally found to increase enabling income diversification and consumption smoothening (Ito \& Kurosaki, 2009).

Against this background, this chapter discusses the evolving role of non-farm income in determining household food security and nutrition in rural India through diversification of incomes and livelihoods. We build upon the idea that promotion of the rural non-farm economy should be an important component of India's rural transformation strategy. We paint a comprehensive portrait of the changing nature of the rural economic structure, blurring of rural-urban distinctions, and how this poses a challenge as well as opportunity to create employment for labor leaving the agricultural sector. The analytical lens of a food system approach here is

\footnotetext{
${ }^{1}$ See chapter on health for discussion on the pathways to reduce malnutrition.

${ }^{2}$ In 2011-12, 84\% of India's population was classified as net consumers of rice, much of which was purchased in the market (CITE).
} 
particularly helpful in imagining rural as farm production and beyondencompassing various food-related non-farm activities such as storage, processing, distribution and transportation of food in addition to many other services which do not necessarily fall within the realm of food production but provide livelihood opportunities to the rural population. ${ }^{3}$

\subsection{Non-farm Sector as Part of the Development STRATEGY}

Livelihood diversification and non-farm employment are important levers for rural economic growth. Across developing countries, the success of the Green Revolution led to the idea of a "unimodal" agrarian structure (Tomich et al., 1995). It was believed that agricultural growth through productivity-enhancing strategies could generate economy-wide growth multipliers, leading to across-the-board income growth and employment generation. While agricultural growth did propel growth and structural transformation in many countries, demographic pressure, preponderance of small farms, declining share of household income from agriculture and commercialization have changed the role of agriculture in future economic growth. Hazell (2018) recognizes a growing differentiation within the agricultural sectors of developing countries. Imagining the future of agriculture, based upon experience in the last 100 years, Hazell argues that the development strategies for rural areas should now prioritize poverty reduction as part of long-term agricultural growth strategy and foster an environment of gainful job creation. Agricultural issues should be focused towards smallholders, specifically increasing their commercially viability through connecting them to markets. Economic changes have reconfigured the roles of culture, institutions, gender and access to human capital in rural areas. At the same time, quality education and health infrastructure, in addition to the issue of access to land, irrigation and other natural resources are increasingly becoming important. Policy focus, therefore, should be on quality jobs, better labor market participation, higher wages and reductions in rural poverty. These arguments further those of Mellor and Johnston (1984) who had argued that reducing poverty and its various manifestations including malnutrition require a concerted attempt of "...interacting forces, characterized as a ring, that link nutritional need, generation of effective demand for food on the part of

\footnotetext{
${ }^{3}$ Many of these points will be discussed in the following chapters.
} 

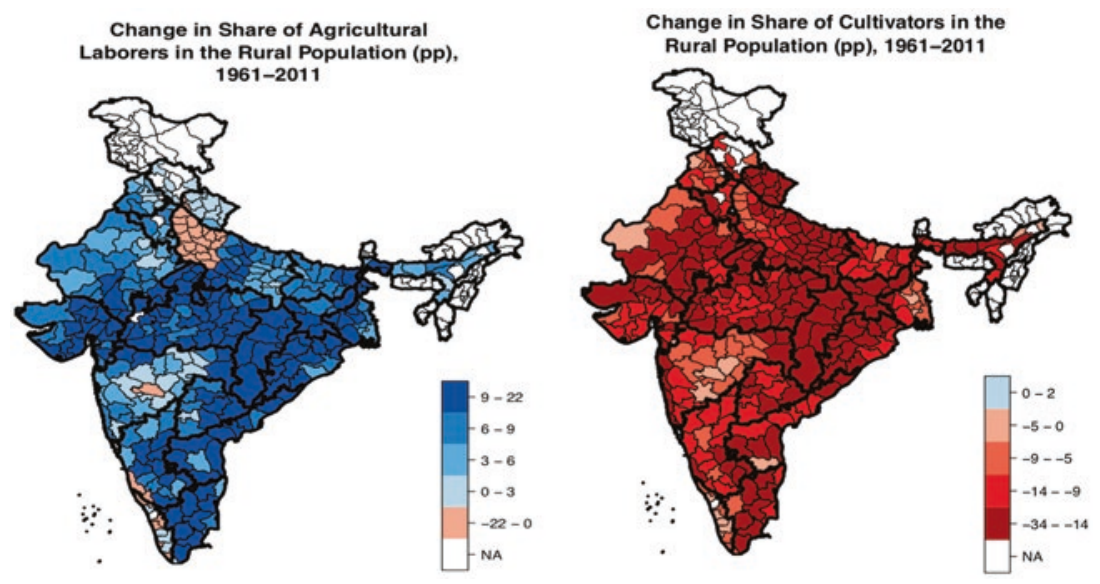

Fig. 3.1 Change in the agricultural workforce. Source: Data from Indian Census 1961-2011, based on author's calculations (Note: We have used data for the major Indian states, and district boundaries represent the 1971 divisions for the sake of comparability over time.)

the poor, increased employment, a strategy of development that structures demand towards goods and services which have a high employment content, production of wage goods, and an emphasis on growth in agriculture". The development strategy path followed by a nation, therefore, is central to how the food equation balances. ${ }^{4}$

The transformation of the workforce in India away from low-productivity agricultural sector into manufacturing and other tertiary activities has been slow. More than $60 \%$ of the rural workforce continues to be employed in agriculture-based livelihoods, despite the share of agriculture output being around $17 \%$. There has been a decline in the share of cultivators, but the share of agricultural labor increased; the desired transition from rural to urban occupation did not take place (Fig. 3.1). Poorer regions specially continue to have a greater share of the rural workforce primarily engaged in agriculture, either as cultivators or wage laborers. In the urbanizing states, and those where agriculture is the driving force, the share of the workforce employed in cultivation is lower (Fig. 3.2). The share of those employed in agriculture-in cultivation and agricultural labor-is highest

\footnotetext{
${ }^{4}$ The food equation is the term used by Malthus in his 1978 "Essay on Population" as a race between food and population. A balanced food equation implies food sufficiency where domestic food demand is met by overall supplies.
} 


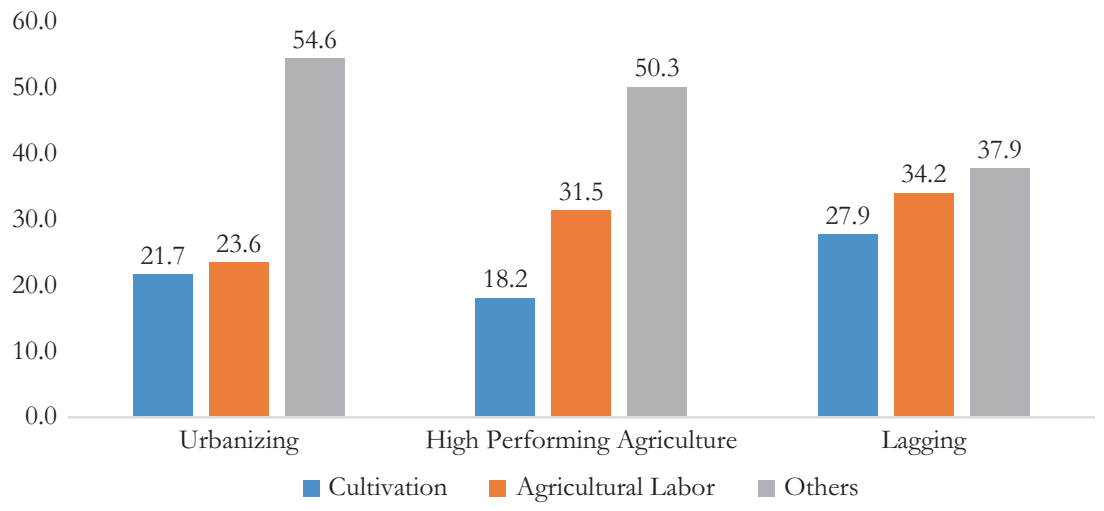

Fig. 3.2 Labor share by state classification. Source: Data from Census of India 2011 ; based on author's calculations

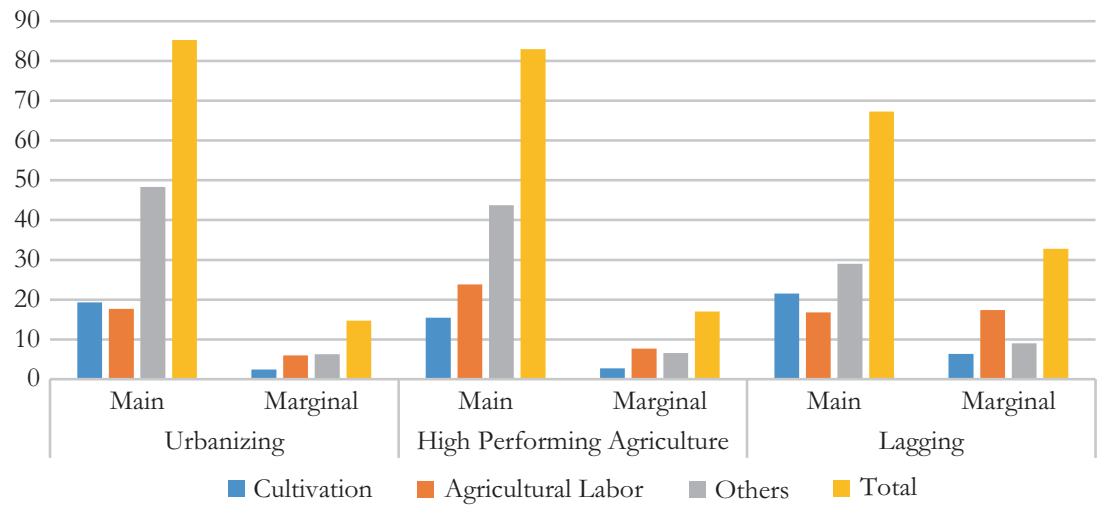

Fig. 3.3 Nature of work: main and marginal workers (in \%). Source: Data from Census of India 2011; based on author's calculations

among the lagging states. Further distinguishing between main and marginal occupation further elucidates the above point. In the lagging states, a greater share of the workforce is also a marginal worker (Fig. 3.3). More advanced states have a lower share of marginal cultivators while the lagging states have marginal workers who are spread across agricultural and nonagricultural occupations. These differentiations help us underscore the point that while India's structural transformation largely has often been 
dubbed as "stunted" (Binswanger-Mkhize, 2013), more nuance lies in subnational variations. Regional variation in land fragmentation and poor access to capital with smallholders has further stifled the desired pace of structural transformation in the lagging regions.

Dynamic changes in the rural economy were historically brought about by Green Revolution productivity increase. These gains, however, were limited to regions which could specialize in the production of staple crops and had better agro-climatic endowments, irrigation and road infrastructure and institutional structures that allowed for better governance of natural resources, such as land and water rights. ${ }^{5}$ In the case of high-productive agriculture states which benefited from the Green Revolution, rise in farm incomes and demand for labor induced higher wage rates which stimulated rural non-farm activities. Rural transformation and greater non-farm employment were brought about by the "pull" forces implying relatively higher returns in the non-farm sector. Income from the non-farm sector is potentially a major poverty-reducing strategy and often picks up the slack when agriculture is not doing well (Haggblade, Hazell, \& Reardon, 2010). It is a widely accepted fact that agricultural households engage in a wide range of economic activities apart from cultivation. A recent nationally representative survey of farmers reflects this phenomenon: only $12 \%$ of the households whose primary source of income is cultivation are not engaged in any secondary activity (Chandrasekhar \& Mehrotra, 2016).

For the first time, in 2012, a greater share of Indian population worked in the non-farm sector. Between 2005 and 2012, about 50 million jobs were created in the non-farm sector, while 34 million jobs were lost in agriculture (Chand, Saxena, \& Rana, 2015). ${ }^{6}$ As the non-farm sector is increasingly becoming more important for Indian rural economy, the official line of thinking on India's agrarian society too has begun to acknowledge rural employment as more than cultivation and agricultural labor. In an interview, Dr. Ramesh Chand, member, agriculture, a government think-tank, NITI Aayog, said, “...it is not proper to view rural India as only an agricultural economy. Now two-third of the economy of rural India is non agriculture and only one-third is agriculture." $\mathrm{He}$ adds,

\footnotetext{
${ }^{5}$ Structural transformation by regions has been dealt with in detail in Chap. 2 .

${ }^{6} \mathrm{~A}$ report by McKinsey Global Institute titled “India's Labour Market: A new emphasis on gainful employment" presents a similar figure. It says that during 2011-15, 33 million nonfarm jobs were created, while the number of agricultural jobs declined by 26 million.

${ }^{7}$ https://www.firstpost.com/business/research-on-agrarian-distress-is-inadequate-weneed-some-proper-indicator-says-ramesh-chand-of-niti-aayog-4795141.html. Accessed on July $24,2018$.
} 
"Ultimately, like China, Japan or any small farm economy, we need to move in the direction of part-time farmers. We recognise that one or two acres will not give them income, they have to earn from other sources. In many cases it is already happening, but we have to move as a development strategy."

\subsubsection{Distributional Implications of Non-farm Income}

Investing in the growth of the non-farm sector is hailed as an important development strategy because of its potential for the redistribution of incomes. Non-farm income acts as a redistribution mechanism in a number of ways (Lanjouw \& Lanjouw, 2001). First, by producing more affordable and lower quality goods consumed mostly by the poor, rural industrial production leads to lower local prices. Second, non-farm economic opportunities provide a source of employment to those for whom agriculture may not provide sustenance and therefore helps to absorb the growing rural labor force, especially in the states which are lagging. Third, through increasing rural livelihood avenues, these types of economic activities help slow down temporary migration (ibid).

India's growth experience suggests a steep rise in inter-personal inequality (Jayaraj \& Subramanian, 2013; Motiram \& Naraparaju, 2015). As the central agrarian question in India remains the availability of productive land, non-farm sector helps maintain income for the landless and the smallholder. It is fairly well established that Indian agriculture is dominated by smallholders, and fragmentation of land is the root cause of poverty and inequality in rural areas (Chakravorty, Chandrasekhar, \& Naraparaju, 2016). Land fragmentation leads to a reduction in the mean plot size below the threshold beyond which mechanization becomes a challenge. This further lowers the economic viability of farms (Deininger, Monchuk, Nagarajan, \& Singh, 2017). While redistribution of land is not a politically attractive option and the consolidation of holdings is operationally challenging, promotion of non-farm opportunities seems to be a more pragmatic way of increasing the income of smallholders and other rural poor. Given the greater pro-poor incidence of non-farm income, historically marginalized sections of the rural society-which have lower access to land and capital-have benefited substantially from the non-farm sector employment despite its casual nature. Similarly, women also benefit from the non-farm sector as their access to resources such as land and jobs remains limited (Lei, Desai, \& Vanneman, 2017). Reduction in inequality 
requires greater access to non-farm jobs which are formal. While non-farm jobs reduce inequality through alleviating unequal access to land (Joshi \& Lanjouw, 2016), formal sector employment would ensure it is more sustainable.

\subsection{Composition of the Rural Non-farm SECTOR IN INDIA}

The important question, however, is to understand the nature of nonfarm sector to understand its welfare implications. Traditionally, the rural non-farm sector comprises of a highly heterogeneous portfolio of activities including services and small-scale manufacturing industries which cater to agricultural input needs and meet the demands of rural consumers (Haggblade et al., 2010). Rural non-farm employment includes food processing or clothing manufacture in the manufacturing sector, in addition to services such as motor repair, or other skilled or unskilled work. Nonfarm workers could also be self-employed through small-scale enterprises and petty trade (Reardon, Stamoulis, \& Pingali, 2007). The nature of the non-farm sector changes as one travels towards villages located closer to towns and other urban centers.

With overall economic growth, better rural infrastructure and declining rural-urban travel time distances, the composition of the rural non-farm sector in India has changed; construction and manufacturing sectors have become major employment sources. According to the estimates based on the National Sample Survey (NSS), construction sector employs $30.1 \%$ of the total non-agricultural employment (Chand et al., 2017). Manufacturing employment, on the other hand, stands at $22.1 \%$, while services employ $45.1 \%$ of the labor force. Unprecedented growth in the construction and the service sector over the last decade has led to a greater number of jobs but also led to greater casualization of the labor force. Lack of formal written contracts between the construction workers and their employers raises the issue of job quality. Even among the formal sector employees in the non-farm economy, such as manufacturing or services, only $60 \%$ have a formal contract, depriving a majority with no social security benefits (Saha \& Verick, 2017). Introduction of the public employment programs, such as MGNREGA, have also facilitated a faster move towards the rural non-farm sector, yet these livelihood avenues are a last resort means for those in the lower income quintile, casting doubts on the long-run welfare of this transition. 
It has been argued that the rise in agricultural productivity abets nonfarm activity (T. Reardon, 1997). In the long run, the expansion of the non-farm sector leads to higher agricultural wages which act as the indirect channel of rural poverty reduction (Lanjouw, 2007). In the Indian context, where education levels are low and vocational skills limited, the non-farm sector is a lucrative alternative for the poor. Over the long run, with a reduction in poverty and investment in future human capital, the non-farm sector could be the springboard for greater economic mobility. The promise of the non-farm sector for abetting human capital investment returns in long-term economic mobility, however, rests on its ability to provide equitable access to quality education, access to well-functioning credit markets as well as the strengthening of the rural-urban linkages.

With agriculture becoming commercialized and a large share of the country expected to be urban by 2050 , most households would be buying food from the market, and hence access to food and nutritional security, therefore, would mostly be determined through the income pathway. Indian policy makers thus face a precarious challenge where they not only need to ensure cultivation is remunerative for greater rural income but also create an enabling environment where quality non-farm economic activities are accessible to a wider rural population which are at a disadvantage because of lack of education, skills, social networks and financial capital.

\subsection{Urbanization AND Growth of THE RuraL ECONOMY}

Urbanization is an outcome of the development process and is intrinsically linked to the evolving food systems. We discuss how urbanization is reshaping diets in Chap. 5. Here, we examine the role of urbanization in contributing to the rural economy through greater employment opportunities. We will specifically address the challenge of meeting the growing urban need for food and other rural resources while at the same time ensuring sustainable rural growth.

Urban areas benefit from agglomeration effects and economies of scale because they can attract a skilled workforce and production inputs are more easily available (Glaeser \& Maré, 2001). The concentration of economic activities leads to technological spillovers and reduced costs of infrastructure provisions. Theoretically, urban economic growth can contribute to reducing rural poverty through two main channels: absorption of surplus labor and productivity spillovers. As per the classic Lewisian 
model, surplus rural labor is absorbed in the urban sector, leading to higher rural wages (Lewis, 1954). Rural poverty reduction is also influenced through greater urbanization and the rise in the demand for rural products. Urban economic growth also affects rural incomes through remittances. The lack of labor-intensive manufacturing sector and adequate urban employment has been one of the reasons why the share of labor in agriculture has not declined commensurate with its declining share in overall output. Similarly, low levels of permanent migration suggest hindrance to rural-urban mobility. At the same time, India's growth story across the globe is of its sprawling metropolises with an abundance of technically skilled manpower and seats of global innovation. The question of our time is therefore how to leverage India's urbanization for greater rural prosperity.

As India is expected to be $60 \%$ urban by 2050 , better infrastructure and communication networks are expected to reduce physical distance and cultural barriers between rural and urban residents. Agriculture, therefore, may no longer continue to be the defining feature of the economic and cultural life in rural areas. This rural transformation-an essential part of structural transformation-entails greater interaction along the ruralurban spaces, thereby promoting agricultural productivity and greater marketable surpluses. This could then facilitate overall production diversification, new forms of livelihood and better infrastructure provision in rural areas. Spatial boundaries across the rural-urban dichotomies are increasingly getting blurred as with larger rural areas becoming indistinguishable from the small urban areas, especially regarding the occupational patterns and built-up area characterizations (Chatterjee, Murgai, \& Rama, 2015). The right set of public policies, however, are essential to ensure smooth, inclusive and sustainable urbanization for structural transformation to take place.

It is now fairly well-established that urbanization has been a significant contributor to rural poverty reduction since 1991 by providing rural households with a greater number of livelihood opportunities during the period when agriculture has largely remained largely stagnant (Chatterjee, Murgai, Narayan, \& Rama, 2016). However, understanding the variegated nature of urbanization is crucial to understand its impact on rural poverty. Urbanization is generally imagined to be the growth of larger metropolises which misses the point that most of the urban population resides in smaller towns. Breaking the monolith of "urban" into its various kinds is therefore very important. Against the common notion which 
equates urbanization with big cities and planning, Indian urbanization has been noted to have a subaltern character, which implies a rapid rise in settlement agglomerations, which are often not classified as urban by the Indian census operations (Denis, Zerah, \& Mukhopadhyay, 2012). The other way to represent these transitions is to call it RUrbanism or Rurality where urban is rapidly integrating with the rural (Chandrasekhar \& Mukhopadhyay, 2017; Revi et al., 2006). Subaltern urbanization, with a growth of small towns in the last decade, has been more prominent in the poorer states (B. Chaudhuri, Chatterjee, Mazumdar, \& Karim, 2017). The urban transition has already matured in the more developed states.

\subsubsection{Emergence of Smaller Towns}

Rural non-farm economy along with the secondary towns contributes significantly to inclusive growth patterns and poverty reduction during the process of rural transformation (Christiaensen \& Todo, 2014). Compared to major urban agglomerations, rural poverty reduction is much stronger if the urban economic growth is driven by smaller towns. These towns provide easier connectivity to the rural hinterland, encouraging labor mobility as well as better access to markets and amenities, including access to human capital. In India, despite all the focus on metropolitan cities as engines of growth, it is actually the smaller towns which have had the biggest impact on poverty reduction during the last two decades (Chatterjee et al., 2016; Gibson, Datt, Murgai, \& Ravallion, 2017). Along the spatial gradient-where the strict rural and urban definitions become blurryagglomeration effects around smaller cities have been the highest as they have led to many high-performing rural places (Li \& Rama, 2015).

In regions where agriculture is the dominant sector and farmers are prosperous, clusters of small towns have emerged. Many of these small towns are market towns often referred to as mandi towns which are centers for agriculture inputs and marketing (Kapur \& Krishnamurthy, 2014). Without expanding enough to become cities, these regions lie along the rural-urban continuum where the principal economic activities are essentially linked to agriculture and consumer demand emanating out of farm income. They comprise facilities for cultivation, input distribution and agricultural marketing yards as well as provide essential consumer goods and services to the villages nearby. Economic activities in smaller towns typically include manufacturing, trades and services. 
Middle spaces between the village and small towns are settlements which Indian census operations call as census towns. India's census operations define census towns (CTs) as urban areas if it has a population of at least 5,000 people, population density is greater than 400 persons per square kilometer and at least $75 \%$ of the main male workforce is employed in the non-farming sector. While this is the standard classification of what is considered as "urban" in India, CTs are peculiar in the way that despite being urban, these settlements continue to be administered as rural areas. The number of census towns between 2001 and 2011 saw a threefold increase from 1,362 to 3,894 contributing to $30 \%$ of the urban population growth, reflecting in situ urbanization (Pradhan, 2013). Unlike CTs, statutory towns (with a population of less than 100,000 ), which either have a municipal corporation, cantonment board or notified town area committee have grown at a relatively slower pace, while census towns have almost doubled from $7.4 \%$ to over 14\% (Mukhopadhyay, Zérah, Samanta, \& Maria, 2016). The rise of census towns together with a greater increase in the built-up area therefore suggests a gross underestimation of urbanization in India.

So, what happens in these census towns and why are they relevant for agricultural growth? These newer towns have become the hub of economic activity and commerce for the rural markets ( $i b i d)$. Proximity to rural areas has also allowed these market towns to become centers for growth, where much of the rural demand for new services and goods are met. This has also allowed them to be distant from the uncertainties of larger metropolises. These smaller towns have not only generated nonfarm employment avenues and contributed to greater rural poverty alleviation but are also the largest growing market for the FMCG sector (Nielsen \& CII, 2012). Many of the small towns or even census towns are zones of transition from an agrarian economy to a more diversified one where manufacturing and services have a greater role. The pace of change, however, varies by the stage of regional rural transformation. There is a different pattern in the regions where agriculture has not been a part of the structural transformation process. In those regions, smaller towns have a greater share of those employed in agriculture. Smaller towns provide employment avenues to those who wish to or are forced to transition out of farming. This is reflected in the greater share of marginal workers in the small towns and rapid emergence of smaller towns and large villages along the poorer regions of Indo-Gangetic plains-like in UP and Bihar (Mukhopadhyay, 2017). Stagnant agriculture, chronic 
underemployment and insufficient job creation in the region have led to the non-farm economy along the rural-urban spaces emerging as the main providers of economic sustenance.

\subsubsection{Peri-urban Areas and Agricultural Growth}

The urban-rural distinction is blurring fast. It is also becoming increasingly hard to distinguish between census towns and towns with urban administrative status. Villages proximate to census towns are not very different from those proximate to statutory towns (Mukhopadhyay, 2017). Instead of a rural-urban binary, we now have a rural-urban continuum which is expanding along with structural transformation of the economy. As villages have begun to exhibit urban characteristics, this phenomenon is often referred to as peri-urbanization. Peri-urban regions are considered as mixed or transitory spaces, undergoing rapid and multiple transformations (Dupont, 2005). While there are issues of disentangling the ruralurban dichotomy, peri-urban agriculture could be a significant contributor to poverty alleviation and food security. Assuming that commuters live in peri-urban areas, Chandrasekhar (2011) estimates them as around 32 million $(4.3 \%$ of the rural population) in India. These commuting workers are primarily engaged in manufacturing, construction and other retail or wholesale sector. Peri-urban regions have become important hubs helping the diversification of economic activity through creating agglomeration effects, and access to amenities and generation of non-farm employment. In villages located closer to towns, the share of non-farm activities could be as large as $70 \%$ (Sharma, 2016). Villages near towns also participate more in intensive agriculture and have higher wages, and households tend to have greater income and consumption expenditure (ibid). Against the common understanding that manufacturing is only restricted to urban areas, formal manufacturing activities in India too have moved from urban to rural environments in the last decade, while urban areas comprise the informal service sector jobs (Ghani, Goswami, \& Kerr, 2012). A substantial share of government and other public sector formal jobs like banking are also located in the rural areas, where people commute daily to work. This form of mobility is reflected in a large share of urban to rural commuter shares. 


\subsection{Policy Strategies to Encourage the Growth of THE Non-farm Sector In India}

Dividing non-farm employment into three categories-regular employment (generally salaried), casual employment (daily wage) and selfemployment-Lanjouw and Murgai (2009) note that regular non-farm employment is the most sought after. Compared to the other two, regular employment in the non-farm sector is associated with higher income and greater stability, but also requires greater skill and better human capital. The challenge for a more vibrant food system is to ensure that movement towards non-farm employment is not a step-down. In this section, we will highlight some of the policy strategies which could be prioritized to encourage the non-farm sector in India.

\subsubsection{Focus on Agriculture and Rural Infrastructure}

A vibrant agricultural sector is essential to the growth of non-farm sector because of the large dependence on it for food security and employment. Most of the rural households do earn a certain part of their income from agriculture while diversifying their income portfolio in India (Chandrasekhar \& Mehrotra, 2016). Agricultural income therefore not only increases the agency of households to command food but also provides resources to take control over other aspects of lives such as investing in children's education, setting up a new enterprise leading to greater accumulation of assets. There could be four major categorizations of the agricultural growth and nonfarm linkages (Lanjouw \& Lanjouw, 2001; Reardon, 1997; Haggblade \& Hazell, 1989). Through production linkages, agriculture connects to nonfarm suppliers of raw materials and farm inputs. There are consumption linkages when the gains from agricultural income are spent on locally produced non-farm goods. Through the supply of labor to non-agricultural activities during the lean season, and investment in non-agricultural activities, agriculture is connected to the economy through factor market. There are productivity linkages through reduced food prices. These linkages, however, assign primacy to the agriculture as a driver of these connections. The reverse takes place too when newer industries could ignite the demand for agricultural products. Similarly, productivity linkages could be induced by the non-farm sector through better input supply, product marketing or investment from non-farm earnings into agriculture for better seeds and fertilizer variety leading to enhanced agricultural productivity. 
An important aspect of restructuring the rural economy is to remove structural constraints to credit and markets. More remunerative nonfarm employment avenues are heavily determined by the density of social networks and family ties, if not by the required degree of skills and training. Often it is the poorest who lack these and are locked out of this market because of marginalized social groups or small land holding. Investment in rural infrastructure goes a long way in reducing the economic distance between rural and urban areas. Reduction in this distance abets rural transformation, integrates markets and thereby facilitates greater access to non-farm employment opportunities, especially for women. Evaluating the impact of a national road expansion program in India, Aggarwal (2018) shows how road infrastructure contributes significantly - through greater dietary diversity and higher agricultural input usage - to the food system. Lei et al. (2017) highlight the importance of rural roads for female employment. Studying the impact of rural road scheme in India, Asher and Novosad (2018), however, caution against assuming road construction, that is, reduction in geographic distance, as the only form of required rural investment. They show that road construction in India led to a 10 percentage point decrease in the share of agricultural workers at the expense of a similar increase in wage labor. Much of this movement took place outside of the village, but it is not permanent migration. These impacts are most pronounced among the groups with the lowest costs and highest potential gains from participation in labor markets: households with small landholdings and working age men. Interestingly, they find that the movers are not the primary income earners of the household. They find that new paved roads under the Pradhan Mantri Gram Sadak Yojana (PMGSY) improve available transportation services facilitating the reallocation of labor out of agriculture. Rural infrastructure is important, but it is only one of the many possible solutions in abetting non-farm occupational transitions. Nonfarm opportunities did not increase in the rural areas; rather roads become a conduit for accessing employment in nearby towns. This finding highlights the fact that road infrastructure is only one way, not the most effective maybe, to increase rural productivity. Better results can be had by facilitating easier movement of labor to areas of better opportunity which point to the importance of urban infrastructure to facilitate rural-urban migration. 


\subsubsection{Governing Census Towns as Urban Areas}

The understanding of rural transformation in India is seriously limited by lack of due recognition to the fact that a large share of rural settlements exhibit urban characteristics, be it through census definitions or as reflected in their built-up areas. Former Union Minister for Rural Development Jairam Ramesh had famously pointed out to this by referring to these spaces as trishanku (middle world). The lack of acknowledgement of changing rural forms also undermines the economic potential of these areas for structural transformation. Future growth of the rural-urban continuum and the creation of greater non-farm opportunities are restricted by the administrative framework which continues to regard census towns as rural areas despite their urban demographic and economic characteristics. It must to be noted that most of the census towns are not near the mega-cities; rather they are dispersed throughout the country, which underscores the greater importance of connecting these spaces to rural areas through moving to urban governance of these spaces. By recognizing these multiple patterns of urbanization, especially its subaltern nature, rural areas could attract investments, job creation and ultimately the benefits from urban growth in the vicinity.

The current government has launched a new program known as the Shyama Prasad Mukberji Rurban Mission (SPMRM), with the objective of developing a "... cluster of villages that preserve and nurture the essence of rural community life with focus on equity and inclusiveness without compromising with the facilities perceived to be essentially urban in nature, thus creating a cluster of "Rurban villages". Under the scheme, 300 rural growth clusters would be created around the country to facilitate local and regional development through higher investments, better infrastructure and service provision in rural areas. The problem with the scheme again lies in not recognizing these changing spaces as urban. The scheme envisages cluster of villages (geographically contiguous with a population of around 25,000-50,000 in plain/coastal areas and of about 5,000-15,000 in desert/hilly/tribal areas) would fall under Gram Panchayats in the same administrative block. The government has designed an agenda for the program on how it wants to facilitate urbanization of the rural (Singh \& Rahman, 2018). Looking at some of the census towns which resemble these potential clusters, Mukhopadhyay et al. (2016) have shown that public service provisioning such as solid waste management and street lighting in census towns is fairly similar to that of villages. Without an appropriate change in the governance frameworks, rural transformations would continue to be constrained. 


\subsubsection{Linking Food Systems to the Jobs Agenda}

Food systems extend far beyond agricultural land and production and provide food, energy and nutrition to the population. At the same time, they also serve an economic and social role through enhancing household access to food. Access comes through income and better jobs. As the food system cut across agriculture, health and nutrition, poverty and the environment, it can also be leveraged to create jobs. Most new jobs in the rural areas would be created in the non-farm sector. As the agricultural value chains develop, there would be greater demand for those who can work in related logistics, from aggregation to storage and processing. With the right set of skills to youth, these sectors could become a major source of job creation. Similarly, rural employment which links to agricultural inputs and mechanization are expected to develop fast with the spread of technology and cellphones. ${ }^{8}$ Hello Tractor in Nigeria is a stellar example of leveraging technology to generate employment avenues in rural areas. Small farmers who cannot afford tractors use this Uber-like facility for on-demand temporary access to tractors. An aggregator in the village arranges for these demands. In India, newer organizations like Gold Farm are using Farming as a Service $(\mathrm{FaaS})$ model where farm equipment can be hired through cellphones or call centers.

Emerging modern food value chains, which include storage, processing, distribution, transportation and retail at the mid-stream and food preparation, and restaurants at the end-stream offer multiple avenues to create gainful employment. These are also the sectors where youth and women can be employed in larger numbers. In a recent report, Future of Food: Shaping the Food System to Deliver Jobs, by the World Bank, some of these aspects are highlighted in the developing world context (Townsend, Benfica, Prasann, \& Lee, 2017). This is especially true for villages in the vicinity of cities or towns. Planners should think of creating agriculture hubs (e.g., processors, agro-industries, storage, packers) for structured food value chains. This would enable an easier transportation of food to the urban population while generating downstream employment concerning moving agricultural produce off the farm and into or through the supply chain. With rural transformation, the size of agribusiness and agricultural value chains increase relative to the farm economy. For example, the agribusiness sector is about half the

\footnotetext{
${ }^{8}$ https://www.thebetterindia.com/137361/gold-farm-equipment-aggregator-startupraises-capital/
} 
economic size of farming in sub-Saharan Africa. In relatively more developed countries of Asia and Latin America, it is about two to three times the size of agriculture; across the developed world, it could be more than ten times as large. In the post-harvest season, when the labor demand in agriculture is low, agribusiness and food value chains offer significant avenues for employment growth. It has been shown that $10 \%$ growth in organized food processing leads to $5 \%$ employment growth in this sector (World Bank, 2015). As per capita incomes increase and eating patterns shift, the demand for jobs in these off-farm segments of the food system will increase. Capitalizing on the same could employ the skilled as well as semi-skilled youth in the hinterlands.

\subsubsection{Skill Enbancement and Investment in Human Capital}

A challenge for policy makers in India, however, has been to provide skills and increase the workforce participation of rural women. A stylized fact is that most rural women in India work on their household farm as unpaid labor. According to the latest census figures, workforce participation rate of rural women is only $30 \%$ compared to $53 \%$ for rural males. Another fundamental feature of women in rural India is their low human capital. On 58\% of the rural women are literate compared to $77 \%$ of rural men. This implies that almost one-fourth of rural non-farm workers in India are illiterate. Lack of education and the required skills inhibit a smooth transition into the non-farm sector. Since construction sector does not require much skills, this sector provides the greatest share of non-farm work. The formal service sector which provides a better quality of employment and written contracts, however, requires more skilled and educated workers. Skilled and educated workers, however, are short in supply. This is a major problem with generating non-farm employment which stems from poor schooling quality in early childhood to lack of vocational training post formal schooling years. While India prides itself in achieving a near-universal school enrolment ratio, it has an abysmal record of actual learning outcome of children (Kingdon, 2007). For the firms, the shortage of skilled labor stems in two ways: lack of a sufficient number of trained personnel and trained people lacking in the required job skills (Mehrotra, 2014). This has been attributed to the outdated syllabus at these vocational institutes which create a mismatch between the quality of training and requirements of the job.

A major challenge for policy makers in India, therefore, is providing quality skills to the workers. Lack of skills has been a major impediment for female employment too. Through the National Policy for Skills 
Development and Entrepreneurship in India, the government is trying to increase women labor participation through skilling and gender mainstreaming of skills. Policy should take a cue from the work of NGOs like the Self-Employed Women's Association (SEWA) where they impart training and skills to women so that they can start their own business. This needs to be prioritized through focusing on the potential of emerging job opportunities through food system transformations in food retail as upstream-downstream opportunities along the agricultural value chains.

\subsubsection{Quality of Non-farm Sector}

The quality of jobs being created in the non-farm sector can be dubbed as ordinary-informal and casual-regarding their potential for rural transformation and lowering structural poverty. The poor quality of rural nonfarm sector jobs especially for women leads to greater withdrawal from the labor market (Chatterjee et al., 2015). Poverty, vulnerability to poverty, and informal employment status are highly associated. Around 79\% of workers who work in the informal sector can be classified as poor without any job or social security (NCEUS, 2008). These workers not only work at low wages, but their working conditions are also miserable. Informality is not particularly specific to rural areas. Even for urban dwellers and migrant, employment and jobs opportunities for the low-skilled workers is nothing but precarious (Breman, 2016).

\subsection{Conclusion}

There are clear complementarities between the development of agricultural and non-agricultural sectors (Foster \& Rosenzweig, 2007). As the agricultural share in the GDP declines, rural non-farm economy becomes a conduit for the resource flows from agriculture to other sectors. Nonfarm economic activities are therefore central to the overall processes of economic growth and changes in the food systems.

Changing economic structure, livelihood opportunities, urban growth opportunities and the commercialization of agriculture-in the course of the structural transformation process - lead to the greater role of markets in accessing food. As a result, means to household food access in the future would be influenced by earning capacities. Farming households would rely on the market value of their produce to access food, whereas the earning capacity of the households dependent upon the non-agricultural sector for 
livelihood would depend upon wages. The blurring of the rural-urban distinction and greater ease of commute are expected to diversify the portfolio of economic opportunities available to the rural households. Greater fragmentation of landholdings would further increase the role of nonfarm sector in facilitating labor movement out of agriculture. This process would lead to a change in the profile of agricultural workers, and economic activities would increasingly become wage-oriented similar to the experience of the developed world. Rising urbanization and urban consumption demand would create fertile opportunities for the nonagricultural workforce to migrate, commute and get employment in food value chains.

Attainment of SDGs-zero hunger and a poverty-free world-therefore depends crucially on how rural areas transform and the nature of their inclusiveness. Given the slow pace of rural transformation in India, the potential for leveraging food systems to propel the growth of the nonfarm sector is immense. Through organized upstream and downstream networks of activities with the emergence of greater agribusiness opportunities, surplus agricultural labor-especially youth and women-are expected to be employed in value chain processes. Such inclusive transformation of rural spaces-by including those who are left out of non-farm employment-is essential to reduce rural poverty.

The other important channel for propelling agricultural growth is to strengthen the rural-urban continuum which provides ample opportunities to the small farmers and other rural population to share in the fruits of urban economic growth. Till now, policy makers in India have not recognized the potential of small towns and the peri-urban spaces to create job opportunities. Recognizing these newer urban settlements and providing them with urban amenities could be a catalyst for non-farm diversification. Local agglomeration economy benefits could be realized through creating clusters of urban-rural spaces which feed the consumer services demand for agricultural households as well as the market for new inputs, technologies and information. The rural-urban continuum would create alternatives to less remunerative migration often resorted as a strategy to escape poverty and hunger and benefit from agglomeration effects from the poorer regions.

While urbanization and changing employment patterns offer opportunities for a more diversified food system, the challenge lies in ensuring these transformations are smooth and contribute to sustainable poverty reduction. Most importantly, the quality of human capital is key to char- 
tering a swifter pace of structural transformation. It has been well documented that India's economic growth has not been able to generate sufficient employment in the manufacturing sector. Similarly, quality service sector jobs require specific skills depending on emerging job requirements; labor transition into the non-farm sector is difficult for most of the farm-based labor. Despite achieving universal enrolment in primary schools, learning outcomes remain low. Similarly, the lack of vocational educational facilities further limits the opportunities to transition into more gainful and formal employment avenues. These are some of the structural issues which have held back the transformation of India's economy in general.

\section{REFERENCES}

Aggarwal, S. (2018). Do rural roads create pathways out of poverty? Evidence from India. Journal of Development Economics, 133, 375-395. https://doi. org/10.1016/j.jdeveco.2018.01.004

Asher, S. E., \& Novosad, P. M. (2018). Rural roads and local economic development. Policy Research Working Paper 8466, World Bank Group, Washington, DC.

Binswanger-Mkhize, H. P. (2013). The stunted structural transformation of the Indian economy: Agriculture, manufacturing and the rural non-farm sector. Economic and Political Weekly, 48, 5-13. Retrieved from https://www.epw. in/journal/2013/26-27/review-rural-affairs-review-issues/stuntedstructuraltransformation-indian

Breman, J. (2016). At work in the informal economy of India: A perspective from the bottom up (OIP). OUP Catalogue.

Chakravorty, S., Chandrasekhar, S., \& Naraparaju, K. (2016). Income generation and inequality in India's agricultural sector: The consequences of land fragmentation. Indira Gandhi Institute of Development Research, Mumbai Working Papers. Indira Gandhi Institute of Development Research, Mumbai, India. Retrieved from https://econpapers.repec.org/RePEc:ind:igiwpp:2016-028

Chand, R., Saxena, R., \& Rana, S. (2015). Estimates and analysis of farm income in India, 1983-84 to 2011-12. Economic and Political Weekly, 50(22), 139-145.

Chand, R., Srivastava, S. K., \& Singh, J. (2017). Changing structure of rural economy of India implications for employment and growth. New Delhi: NITI Aayog.

Chandrasekhar, S. (2011). Workers commuting between the rural and urban: Estimates from NSSO data. Economic and Political Weekly, 46(46), 22-25. Retrieved from http://www.jstor.org/stable/41319397

Chandrasekhar, S., \& Mehrotra, N. (2016). Doubling farmers' incomes by 2022. Economic \& Political Weekly, 51(18), 10-13. 
Chandrasekhar, S., \& Mukhopadhyay, A. (2017). The changing nature of rurality: Reframing the discourse on migration and commuting. In Rural labour mobility in times of structural transformation (pp. 183-207). Singapore: Springer Singapore. https://doi.org/10.1007/978-981-10-5628-4_9

Chatterjee, U., Murgai, R., Narayan, A., \& Rama, M. (2016). Pathways to reducing poverty and sharing prosperity in India: Lessons from the last two decades. World Bank.

Chatterjee, U., Murgai, R., \& Rama, M. (2015). Employment outcomes along the rural-urban gradation. Economic \& Political Weekly, 50(26 \& 27), 5-10. Retrieved from http://www.epw.in/system/files/pdf/2015_50/26-27/ Employment_Outcomes_along_the_RuralUrban_Gradation.pdf

Chaudhuri, B., Chatterjee, B., Mazumdar, M., \& Karim, S. (2017). Income ranking of Indian states and their pattern of urbanisation. In E. Denis \& M.-H. Zérah (Eds.), Subaltern urbanisation in India. Exploring urban change in South Asia (pp. 91-118). https://doi.org/10.1007/978-81-322-3616-0_4

Christiaensen, L., \& Todo, Y. (2014). Poverty reduction during the rural-urban transformation-The role of the missing middle. World Development, 63, 43-58. https://doi.org/10.1016/j.worlddev.2013.10.002

Deininger, K., Monchuk, D., Nagarajan, H. K., \& Singh, S. K. (2017). Does land fragmentation increase the cost of cultivation? Evidence from India. The Journal of Development Studies, 53(1), 82-98. https://doi.org/10.1080/00220388. 2016.1166210

Denis, E., Zerah, M.-H., \& Mukhopadhyay, P. (2012). Subaltern urbanisation in India. Economic and Political Weekly. Retrieved from https://www.epw.in/ journal/2012/30/review-urban-affairs-review-issues/subaltern-urbanisationindia.html

Dupont, V. (2005). Peri-urban dynamics: Population, habitat and environment on the peripheries of large Indian metropolises: An introduction. CSH Occasional Paper 14, Centre de Sciences Humaines, New Delhi.

Ellis, F. (1998). Household strategies and rural livelihood diversification. Journal of Development Studies, 35(1), 1-38. https://doi.org/10.1080/ 00220389808422553

Foster, A. D., \& Rosenzweig, M. R. (2007). Chapter 47, Economic development and the decline of agricultural employment (pp. 3051-3083). https://doi. org/10.1016/S1573-4471(07)04047-8

Ghani, E., Goswami, A. G., \& Kerr, W. R. (2012). Is India's manufacturing sector moving away from cities? Policy Research Working Papers, The World Bank. https://doi.org/10.1596/1813-9450-6271

Gibson, J., Datt, G., Murgai, R., \& Ravallion, M. (2017). For India's rural poor, growing towns matter more than growing cities. World Development, 98, 413-429. https://doi.org/10.1016/j.worlddev.2017.05.014 
Glaeser, E. L., \& Maré, D. C. (2001). Cities and skills. Journal of Labor Economics, 19(2), 316-342. https://doi.org/10.1086/319563

Haggblade, S., \& Hazell, P. (1989). Agricultural technology and farm-nonfarm growth linkages. Agricultural Economics, 3(4), 345-364.

Haggblade, S., Hazell, P., \& Reardon, T. (2010). The rural non-farm economy: Prospects for growth and poverty reduction. World Development, 38(10), 1429-1441. https://doi.org/10.1016/j.worlddev.2009.06.008

Hazell, P. (2018). Urbanization, agriculture and smallholder farming. In R. Serraj \& P. Pingali (Eds.), Agriculture and food systems to 2050: Global trend, challenges and opportunities (pp. 137-160). Singapore: World Scientific.

Ito, T., \& Kurosaki, T. (2009). Weather risk, wages in kind, and the offfarm labor supply of agricultural households in a developing country. American Journal of Agricultural Economics, 91(3), 697-710. https://doi. org/10.1111/j.1467-8276.2009.01270.x

Jayaraj, D., \& Subramanian, S. (2013). On the inter-group inclusiveness of India's consumption expenditure growth. Economic and Political Weekly, $X \operatorname{LVIII}(10), 65-70$.

Joshi, B., \& Lanjouw, P. (2016). Non-farm diversification, inequality and mobility in Palanpur. Economic and Political Weekly, 51(26-27), 43-51.

Kapur, D., \& Krishnamurthy, M. (2014). Market towns and the dynamics of India's rural and urban transformations. Working Paper, International Growth Center.

Kingdon, G. G. (2007). The progress of school education in India. Oxford Review of Economic Policy, 23(2), 168-195. https://doi.org/10.1093/oxrep/grm015

Lanjouw, J. O., \& Lanjouw, P. (2001). The rural non-farm sector: Issues and evidence from developing countries. Agricultural Economics, 26(1), 1-23. https://doi.org/10.1111/j.1574-0862.2001.tb00051.x

Lanjouw, P. (2007). Does the rural nonfarm economy contribute to poverty reduction. In S. Haggblade, P. B. R. Hazell, \& T. Reardon (Eds.), Transforming the rural nonfarm economy: Opportunities and threats in the developing world (pp. 55-82). Johns Hopkins University Press.

Lanjouw, P., \& Murgai, R. (2009). Poverty decline, agricultural wages, and nonfarm employment in rural India: 1983-2004. Agricultural Economics, 40(2), 243-263. https://doi.org/10.1111/j.1574-0862.2009.00373.x

Lei, L., Desai, S., \& Vanneman, R. (2017). Village transportation infrastructure and women's non-agricultural employment in India: The conditioning role of community gender context. IHDS Working Paper No. 2017-2.

Lewis, W. A. (1954). Economic development with unlimited supplies of labour. The Manchester School, 22(2), 139-191. https://doi.org/10.1111/ j.1467-9957.1954.tb00021.x

Li, Y., \& Rama, M. (2015). Households or locations? Cities, catchment areas and prosperity in India. World Bank Policy Research Working Paper No. 7473. 
Mehrotra, S. (2014). India's skills challenge: Reforming vocational education and training to harness the demographic dividend. Oxford University Press.

Mellor, J. W., \& Johnston, B. F. (1984). The world food equation: Interrelations among development, employment, and food consumption. Journal of Economic Literature, 22(2), 531-574.

Mishra, S., \& Rahman, A. (2018). Does non-farm income affect food security? Evidence from India. Mimeo.

Motiram, S., \& Naraparaju, K. (2015). Growth and deprivation in India: What does recent evidence suggest on "Inclusiveness"? Oxford Development Studies, 43(2), 145-164. https://doi.org/10.1080/13600818.2014.988693

Mukhopadhyay, P. (2017). Does administrative status matter for small towns in India? In E. Denis \& M.-H. Zérah (Eds.), Subaltern urbanisation in India: An introduction to the dynamics of ordinary towns (pp. 443-469). New Delhi: Springer India. https://doi.org/10.1007/978-81-322-3616-0_17

Mukhopadhyay, P., Zérah, M.-H., Samanta, G., \& Maria, A. (2016). Understanding India's urban frontier: What is behind the emergence of census towns in India? The World Bank. https://doi.org/10.1596/1813-9450-7923

National Commission for Enterprises in the Unorganised Sector (NCEUS). (2008). Report on definitional and statistical issues relating to informal economy.

Nielsen, \& CII. (2012). Emerging consumer demand: Rise of the small town Indian.

Pingali, P., \& Sunder, N. (2017). Transitioning toward nutrition-sensitive food systems in developing countries. Annual Review of Resource Economics, 9(1), 439-459. https://doi.org/10.1146/annurev-resource-100516-053552

Pradhan, K. C. (2013). Unacknowledged urbanisation. Economic and Political Weekly. Retrieved from https://www.epw.in/journal/2013/36/special-articles/unacknowledged-urbanisation.html

Reardon, T. (1997). Using evidence of household income diversification to inform study of the rural nonfarm labor market in Africa. World Development, 25(5), 735-747. https://doi.org/10.1016/S0305-750X(96)00137-4

Reardon, T., Stamoulis, K., \& Pingali, P. (2007). Rural nonfarm employment in developing countries in an era of globalization. Agricultural Economics, 37, 173-183. https://doi.org/10.1111/j.1574-0862.2007.00243.x

Revi, A., Prakash, S., Mehrotra, R., Bhat, G. K., Gupta, K., \& Gore, R. (2006). Goa 2100: The transition to a sustainable RUrban design. Environment and Urbanization, 18(1), 51-65. https://doi.org/10.1177/0956247806063941

Saha, P., \& Verick, S. (2017). Casualization and shift of rural workers to non-farm activities. In Rural labour mobility in times of structural transformation (pp. 127-150). Singapore: Springer Singapore. https://doi.org/10.1007/ 978-981-10-5628-4_7

Sharma, A. (2016). Urban proximity and spatial pattern of land use and development in rural India. The Journal of Development Studies, 52(11), 1593-1611. https://doi.org/10.1080/00220388.2016.1166207 
Singh, C., \& Rahman, A. (2018). Urbanising the rural: Reflections on India's National RUrban Mission. Asia \& the Pacific Policy Studies, 5(2), 370-377. https://doi.org/10.1002/app5.234

Tomich, T. P., Kilby, P., \& Johnston, B. F. (1995). Transforming agrarian economies: Opportunities seized, opportunities missed. Cornell University Press.

Townsend, R., Benfica, R. M., Prasann, A., \& Lee, M. (2017). Future of food: Shaping the food system to deliver jobs. Washington, DC: World Bank.

World Bank. (2015). Ending poverty and hunger by 2030: An agenda for the global food system. Retrieved from http://documents.worldbank.org/curated/en/ 700061468334490682 /pdf/95768-REVISED-WP-PUBLIC-Box391467BEnding-Poverty-and-Hunger-by-2030-FINAL.pdf

Open Access This chapter is licensed under the terms of the Creative Commons Attribution 4.0 International License (http://creativecommons.org/licenses/ by $/ 4.0 /$ ), which permits use, sharing, adaptation, distribution and reproduction in any medium or format, as long as you give appropriate credit to the original author(s) and the source, provide a link to the Creative Commons licence and indicate if changes were made.

The images or other third party material in this chapter are included in the chapter's Creative Commons licence, unless indicated otherwise in a credit line to the material. If material is not included in the chapter's Creative Commons licence and your intended use is not permitted by statutory regulation or exceeds the permitted use, you will need to obtain permission directly from the copyright holder.

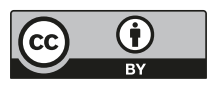

